投稿論文

\title{
GMO 貿易と国際規制一構造と展望一
}

\section{一橋大学 山川 俊和 ${ }^{*}$}

\section{1.はじめに}

「安全性（Safety）」問題が日々の報道を賑わし続けている。鳥インフルエン ザに代表される感染症や，バイオテクノロジーの商業利用など，農産物・食品 に由来する「安全性問題」への注目はますます高まっているようにみえる1。

日米のBSE交渉が想起されるように，安全性問題と農産物・食品貿易の関 係は, 国際経済政策上の重要課題となっている。そして, 貿易と安全性問題を めぐっては，「疑わしきは罰せず」を基本スタンスとしながら自由貿易の推進 をはかるアメリカら輸出国と,「予防原則 (Precautionary Principle)」を基本的 なアプローチとしながら貿易政策と安全性問題を調整しょうとする欧州連合 （EU）との対立が顕著である2）。

この対立が含意するのは, 特定の化学物質や添加物, あるいは遺伝子組み換 え体 (Genetically Modified Organism, GMO)，GM作物そしてGM食品のような， バイオテクノロジーの使用に起因して安全性が疑問視されている財の貿易をい かにコントロールするか，その場合の「ルール」はどうあるべきか，という論 点である。

「貿易と環境・安全性」に関する貿易措置を規定する「ルール」は，1980年 代後半から1990年代にかけ徐々に形成されてきた ${ }^{3)}$ 。GATT/WTO，そして京都

*一橋大学大学院経済学研究科博士課程（yamakawatoshikazu@gmail.com）本稿の一部は, 第65回日本国際経済学会全国大会 (名古屋大学) において発表した「貿易ルールと安全 性問題」に基づいている。 
議定書やバーゼル条約といった多国間環境協定（MEA）などの「国際レジー ム」に扔いて，「ルール」の展開をみることができる゙う。の「ルール」こそ， 今日の「貿易と環境・安全性」を捉えるにあたり必要不可欠な事柄であり，こ こではそれを「環境・安全性関連貿易ルール」と呼ぶこととする5)。

本稿では，その社会経済的な影響の大きさから近年ますます注目を集めてい る，GMOを取り上げる。そして，その国際移動（㧍よび規制措置）を定めた 「バイオセーフテイに関するカルタへナ議定書（The Cartagena Protocol on Biosafety)」(以下，カルタヘナ議定書）を中心として，GMO貿易の国際規制 について検討する゙ ${ }^{6}$ 。

本稿の狙いは, 複雑に入り組んだ国際 $\mathrm{GM}$ 規制レジームの構造を明らかにす るとともに，今後の行方を展望することにある。そして，「貿易と環境・安全 性」の「見方」を「ルール」という切り口から提示することもまた，その射程 に収めている。

以下では，まず「貿易と環境・安全性」に関する基本的な問題の所在を確認 する。次に, 国際 $\mathrm{GM}$ 規制レジームについて, カルタへナ議定書を中心に検討 する。そして最後に, EUの GMO 規制に対するWTO紛争処理システムの判断 を紹介しつつ, 今後の国際 $\mathrm{GM}$ 規制レジームに関し，若干の展望を記す。

\section{2.「貿易と環境・安全性」をめぐって}

本節の目的は，「貿易と環境・安全性」に関する基本的な問題の所在を確認 することである。自由貿易レジームと環境・安全性問題との関係を概観し，国 際貿易に损ける環境・安全性問題の位置付けを政治経济学的な視座から行って い。

\section{1.自由貿易レジームと環境・安全性}

環境・安全性問題，そして開発や労働，投資といった諸問題は，これまで, 国際貿易システムとの関係が直接的に認識されてこなかった。しかし，これら 
諸問題は「非貿易的関心事項」と呼ばれ，現在様々な立場から注目されてい $ろ^{7)}$ 。環境・安全性問題の文脈からは, 自由貿易を規範とする「自由貿易レジ 一ム」(GATT/WTO) に，環境・安全性といった新たな価值規範をいかに導入 するか。また，京都議定書や後述するカル夕へナ議定書のように，多国間で取 り決められた「環境レジーム」との関係はどうあるべきか，という点が問われ ている ${ }^{8)}$ 。これからの国際貿易システムは, 非貿易的関心事項の取り扱い次第 で，その姿を大きく変えてくるかもしれない。

さて，非貿易的関心事項の台頭により貿易政策のカバレッジが広がっている ことに批判的な立場をとるバグワッティは，「適切なガバナンス」論を展開し ている（Bhagwati, 2000）。環境はUNEP，労働はILOといった形でそれぞれの 専門機関に任せ，WTOは貿易自由化のためのフォーラムに限定せよ，という 主張がそれである。なるほど，自由貿易体制が掘り崩されることを何よりも懸 念するバグワッティらしい提言だといえる。バグワッティが強調するように， 自由貿易の利益を軽視すべきでは，もちろんない。とはいえ，彼の議論の問題 点は，自由貿易の利益を強調しすぎる「規範的」議論であるとともに，イシュ ーごとの具体性にそしいことである。それゆえ，国際貿易システムのあり方を 模索する政策研究としては，㧍そらく不十分であると思われる9

WTOを設立するマラケシュ協定の前文をみると，1992年のリオサミットを 受け，「持続可能な発展 (Sustainable Development)」を達成することを目的と して謳っている。だが現状に扔いて，具体的なルールとその運用のあり方に関 する，加盟国間のコンセンサスは確定していない。この点に関連して天野 （2006）は，GATT/WTO体制は貿易自由化と経済発展には寄与したが，環境問 題への対応は十分とはいえない。MEAは参加国に対して法的拘束力を持った 体制が整っているという点では，まだGATT/WTOに比肩できるには至ってい ない。むしろ，不調和の方が目立つとし，「貿易と環境・安全性」に関する具 体的な紛争や事例の分析が必要であることを強調している。

また，WTO内部でも環境NGOとの良好な関係が模索されていること的，そ 
して「貿易と環境・安全性」に関する紛争が積み上げられ様々な条約が形成さ れている現状を踏まえるならば，「貿易と環境・安全性」の相互連関構造に対 する政治経済学的分析に一定の意義を見出すことができよう。

\section{2.貿易政策思想と環境・安全性}

「貿易と環境・安全性」に接近するにあたっては，貿易政策をどう捉えるか が大きな意味を持つ。おそらく貿易政策として市民権を得ているのは，「自由 貿易（Free Trade）」と「保護（貿易）主義（Protectionism）」，すなわち「自由 か保護か」の構図であろう。

この点に関し森田桐郎は, 「自由貿易主義と保護貿易主義とは, それぞれ特 定の歴史的状況のもとで, 特定の意味, 特定の利害を担って登場するものであ って，そのいずれかが普遍的・絶対的に正しいと断ずることはできない。すな わち，両者を形式的に対立関係に扔いて，いずれが一般的に正しいかを論ずる のではなく，それぞれの政策的主張が出てくるその基礎を理解することが重要」 （森田, 1995:93）とし，両思想の「相対化」を求めている。

森田が指摘するように，「自由か保護か」という主張の背景にこそ目を向け ること, さらには, その主張の対抗が, 各国の「産業利益」をめぐり展開されて いる点に注目することが重要である ${ }^{11)}$ 。その上で, 「貿易と環境・安全性」を

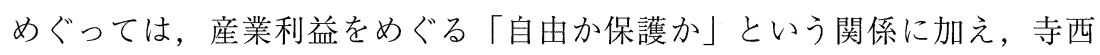
（1992）で示されたように，新しく主張されてきた「環境保全の利益」を受け 止める必要があろう。寺西俊一は, この自由貿易, 保護貿易, 環境保全の各利 益をめぐる構図を，理念的に「三つどもえの対抗」と呼んでいる。

持続可能な発展の達成には, 環境保護のための措置や政策を, 自由貿易レジ 一ムとの関倸に扔いて明示的に位置づけることが求められる。そして，この措 置・政策は旧来の「産業利益」の論理に基づく「保護主義」とは異なる環境 「保護」政策である。ただ，環境・安全性に関する規制なり政策によって貿易 の自由度が損なわれると，この制限が「環境（安全性）保護」か，あるいは 
図 1 「貿易と環境・安全性」の構図

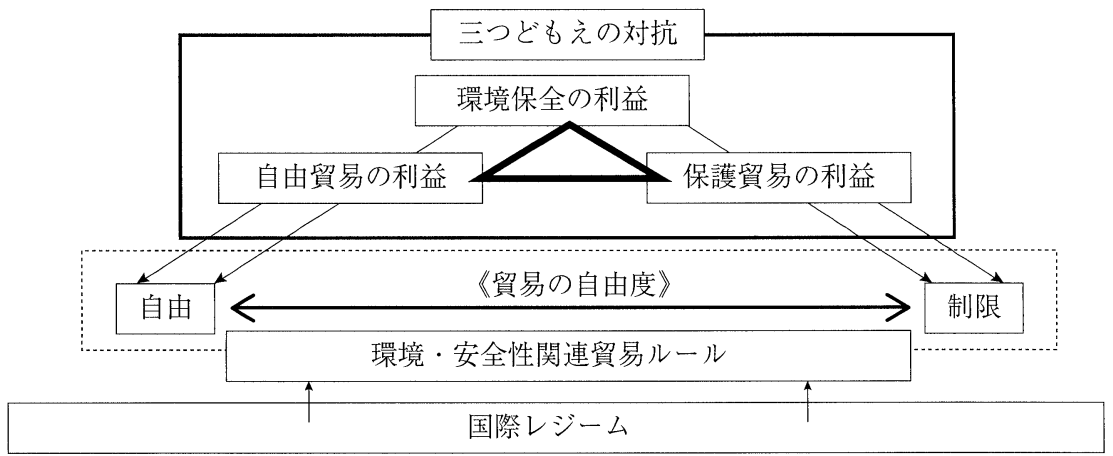

（出所）筆者作成

「(産業) 保護主義」なのか，という点が問われるようになる。二つの「保護」 が重複することにより，「貿易と環境・安全性」に関する議論はより複雑とな る。いわゆる「保護か保護主義か」という論点は, 特に安全性をめぐる紛争に しばしば登場してくる。これまでの議論を，レジームとルールの関係と合わせ， 図 1 に記した。

\section{GMOの現状と問題点, 国際規制レジーム一カルタヘナ議定書を中心に}

WTO体制下の「貿易と環境・安全性」に共通する政策論的争点として, GATT20条（一般的例外）とMEA との関係，環境に関係する PPMs ${ }^{12}$ ，予防原 則のより広い範囲の適応が挙げられる（Martin, 2001）。その争点は, GMO貿 易とその規制にも妥当している。本節では，GMOをめぐる諸問題について， 国際貿易にかかわる論点を中心にみていく。

\subsection{GMO の現状と問題点}

\section{(1)GMO生産の現状}

ここでは，いくつかの定量・定性的な資料を用いて GMOの現状を確認し， 
表 1 各国のGM作物生産対応状況（2004年統計）

\begin{tabular}{|c|c|c|}
\hline & 先進国（作付面積と割合） & 発展途上国（作付面積と割合） \\
\hline 積極 & $\begin{array}{r}\text { 米国 }(47.6 \text { 万ha }: 59 \%) \\
\text { カナダ }(5.0 \text { 万ha }: 6 \%) \\
\text { 南アフリカ }(0.5 \text { 万ha }: 1 \%)\end{array}$ & $\begin{array}{r}\text { アルゼンチン }(16.2 \text { 万ha }: 20 \%) \\
\text { 中国 }(3.7 \text { 万ha }: 5 \%)\end{array}$ \\
\hline 中間 & $\begin{array}{l}\text { オーストラリア } \\
\text { ニュージーランド }\end{array}$ & $\begin{array}{r}\text { アフリカ諸国 } \\
\text { 中南米諸国 } \\
\text { ブラジル }(5 \text { 万ha } ： 6 \%) \\
\text { 《積極路線：10\%に増加中》 }\end{array}$ \\
\hline 慎重 & EU, 日本, 韓国 & ASEAN 諸国 \\
\hline
\end{tabular}

(出所) 渡部（2003）をもとに, 統計などを加え筆者作成

GMOが有している問題点について述べる。

現在, GMOの栽培品目は，その割合順に，大豆が約 $60 \%$ ，次いでトウモロ コシ，綿花となっている。そのうち性質別の割合では，「除草剂耐性（雑草防 除のための除草剂の散布を減少)」が70.8\%，「害虫抵抗性（害虫駆除のための 殺虫剂の使用を減少)」が $18.0 \%$ ，両者の性格を合わせた「両性付与」が $11.2 \%$ である。これら性質の GMOは「第一世代」と呼ばれており，さらに現在，環境 ストレス耐性，健康増進機能を有する GMO，通称「第二世代」が開発中であ る。

GM作物の作付面積は，1996年にはわずか 1.7 万haに過ぎなかったが，2000年 には44.2万ha，そして2004年には世界で約 81 万haを誇っており，ここ10年弱の 間に右肩上がりで増加している。表 1 では，各国の GM作物生産対応状況およ びポジションを三段階に分けて整理している。特徴としては，ブラジルの生産 割合が10\%（2005年）に伸びていることが挙げられる。これは，ブラジルが対 GMO 政策を変更したことにより，積極路線へとシフトした影響だと思われる。 GMOについては，中国，インドを含め新興成長国の動向にはとりわけ注意が 必要であろう。そして, 米国やカナダといった非ヨーロッパの農産物・食品生 産大国はGMOの生産に対しても積極的であることが指摘できる。後述するよ 
うにこのポジションの違いはGMO 貿易をめぐるコンフリクトにも大きく影 響している。

\section{(2)GMOの問題点}

GM作物の利点としてはしばしば，農家にとっての手間，生産コストが減少 し, 収量が拡大するという「生産者便益論」，そして発展途上国の食糧不足を 解決する切り札であるとの主張が展開される。この主張は，GM技術の広範な 拡大, さらには GMO $\cdot \mathrm{GM}$ 食品の貿易自由化という主張へと繋がっている。 しかし，多くの論者が指摘するように，GMOとその推進要求は，無批判に受 け入れられるものではない。

平川（2003a）は，GMOに起因するリスクを，「物理的リスク」と「社会的 リスク」に分類する（表 2 ）。この「リスク」の存在は, 単なる生産物や商品 として GMO を捉えることの不適切さを示すとともに，GMOをめぐる南北問 題と多国籍企業の動向の重要性を示唆する。また，久野（2002）は，生産者便 益論を批判する形で，企業による種子独占の問題に言及し，GMOの生産と貿 易の担い手である多国籍バイオ企業へと分析のメスを入れている。GMOの社 会的リスクについては, 途上国開発・南北問題論との接点から，一層の研究が 求められよう。

さて，OECDによれば食品の安全性（Food Safety）の概念は「人体への細菌， 毒素, 病原体, 化学残留物質のリスクと動植物に影響を与えうる病気あるいは 寄生虫のリスク」(OECD, 1999:12）と規定される。WTOの付属協定である SPS 協定も同様の概念に基づく制度設計がなされている 夕ヘナ議定書にも影響を与えている。すなわち, WTOの制度, 特にSPS協定 との関係では，「環境・安全性関連貿易ルール」が直接規制の対象としている のは, 表 2 でいうところの「物理的リスク」, 中でも人体に影響を与える「健 康リスク」と「生物学的原因による生態リスク」である。この点を踏まえ, 国 際 GM規制レジームについて，次で検討しよう。 


\section{表 2 GMOのリスク}

《物理的リスク》

・健康リスク：短期，長期のアレルギー性その他の毒性，抗生物質抵抗性など。

・生物学的原因による生態リスク：GM作物の栽培が生態系に及ぼす直接的な悪影響。

(1)導入遺伝子が他の植物に拡散する遺伝子污染。

(2)新たな病原体や雑草・害虫の対抗進化。

(3)導入遺伝子が作る毒素たんぱく質による標的外昆虫や土塨微生物の生態系への 意図しない影響。

・社会的要因による生態リスク：アグリビジネスによる種子支配とモノカルチャー 農業による農業生態系の均一化・不安定化・脆弱化。

\section{《社会的リスク》}

・社会経済的リスク：生物特許による生物資源の私有化によるアグリビジネスの種 子支配と垂直統合の進行。途上国の伝統的知識の私物化（バイオパイラシー）の 危険。種子支配による農家の自家採取・自家改良の権利の侵害と, 小規模農家へ の社会経済的影響（生産コスト増大や自営基盤の解体，借金増による離農など）。 途上国での輸出換金作物偏重・市場依存強化による自給農業の衰退，飢餓輸出の 悪化，貧富の差の拡大。

・文化的リスク：バイオパイラシー。多様な農業の伝統的知識・実践の衰退や代替 的方法の排除。食文化や宗教的・倫理的な価值などの文化的な独自性の侵害。

・政治的リスク：GM製品輸入に対する独自のリスク評価と規制の困難化。生物特許 の紛争解決の困難化。消費者の「選択の権利」の侵害。

(出所) 平川（2003a:128）をもとに筆者作成

\section{2. カルタヘナ議定書に基づく貿易規制}

カルタヘナ議定書は2000年に採択，2003年 9 月に発効している（日本は同年 11月に批准し，国内法は04月 2 日に発効している）14）。議定書は「生物多様性 の保全と持続可能な利用に悪影響を及ぼす可能性のあるLMO (Living Modified Organism）の安全な移送，取り扱い及び利用の分野において十分な水準の 保護を確保すること」を目的としている

LMO とは，次に記す三つの性質を有するものを意味する。すなわち，(1)環 境への意罒的な導入を目的とするもの（たとえば，栽培用種子），(2)食料もし 


\section{図 2 AIA 手続きの流れ}

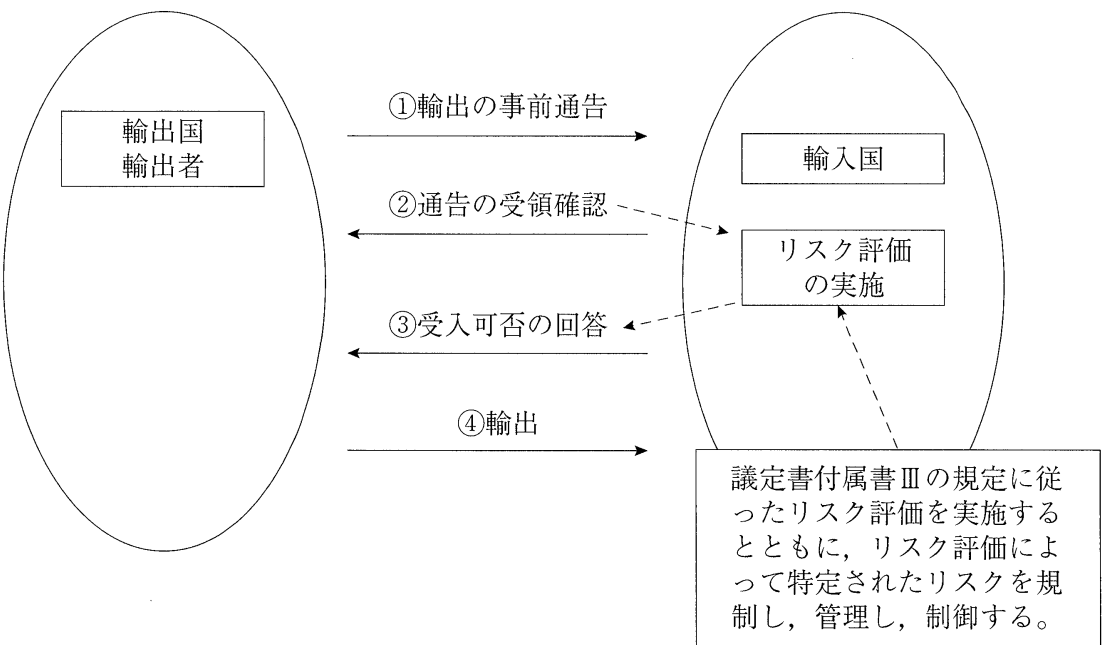

出所）日本バイオセーフティクリアリングハウス（http://www.bch.biodic.go.jp/）を参考に著者作成 (2006年12月20日アクセス)

くは飼料として直接利用しまたは加工することを目的とするもの，(3拡散防止 措置の下での利用を目的とするもの，である。そして，環境への意困的な導入 を目的とするLMO（栽培用種子など）の輸出入に際しては，「事前の通告によ る同意（AIA）」手続きが必要であると規定し，自由な貿易を規制している。 AIA 手続きの流れを図示したのが図 2 である。

カルタヘナ議定書には, 輸出国（または輸出者）は，LMOの意困的な国境 を越える移動に先立ち，輸入国に対して通告を行い，輸入国はその情報を踏ま え，リスク評価を実施し輸入の可否を決定することが定められている ${ }^{16 ） 。 今 み ~}$ た手続きのように，様々なリスクが懸念される GMOの貿易を，特定の「ルー ル」の下で行うことを議定書は定めている ${ }^{17)}$ 。

カルタヘナ議定書に基づく規制の評価については，特にNGO 的な立場から 好意的に受け止められている（Martin, 2001）。事実, GMOの有している「安 全性問題」が輸入国サイドで発生することを考えても，予防的アプローチを不 
完全ながら導入することに成功し，自由貿易を一定程度相対化し輸入国サイド へとリスク評価の権利を付与したという点に扔いて，特徴的かつ意義の大きい 「環境・安全性関連貿易ルール」であるといえよう。

ただ，カルタへナ議定書の存在だけで，GMOの貿易・国際移動に関する問 題が万事解決すると結論付けるのは早計である。

まず，「対象範囲」に関する問题がある。カルタへナ議定書では，GMO由来 の加工品は規制の対象としていない。それゆえ，GMOの意図せざる混入に関 する許容限度や，GM食品へのラベリングも議定書の規制対象から外れてしま うのである。これらの点は，EUとアメリカの貿易紛争の火種となっている。

さらに，「レジーム・コンフリクト」の問題が挙げられる。現在，超国家的 な機関が存在して㧍らず，協定や委員会べースで行われる GMO の国際規制は， 幾つかのレジームが混在し，「つぎはぎ」状態である（表 3 ）。このような規制 レジームの結果として，カルタへナ議定書の「ルール」を適応することができ ない国が出てくる，例えばアメリカである ${ }^{18)}$ 。また，カル夕へナ議定書に基づ

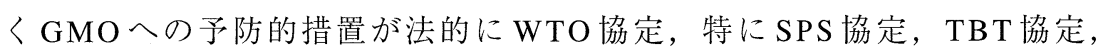
GATT1994と抵触する可能性が指摘されている（藤岡, 2006)。このようなカル 夕へナ議定書とWTOの抵触・優先順位問題は, WTO とMEAの関係という 「環境・安全性関連貿易ルール」に扔ける争点と重なり合っている。

\section{WTO の判断と国際 GM 規制レジームの今後一むすびにかえて}

これまでの国際 $\mathrm{GM}$ 規制レジームについての議論を受け，本節では，GM規 制をめぐるアメリカとEU の紛争に関するWTO の判断についてみる。その動 向を踏まえ，これからの国際 $\mathrm{GM}$ 規制レジームに関する若干の展望を記し，む すびにかえたい。

\subsection{GMOをめぐるWTOの判断}

2006年 9 月29日にEUのバイオテクノロジー製品承認・販売に影響を与える 78 
表 3 GMO貿易に関連する「つぎはぎの」国際規制レジーム

\begin{tabular}{|c|c|c|c|c|c|}
\hline 機関名 & 設立年 & 活動対象の範囲 & 加盟国数 & 紛争解決 & GM作物·食品への対応 \\
\hline $\begin{array}{l}\text { 国際獣疫 } \\
\text { 事務局 } \\
\text { (OIE) }\end{array}$ & 1924 & $\begin{array}{l}\text { 動物及び動物製 } \\
\text { 品の伝染病及び } \\
\text { 病原体 }\end{array}$ & 167 & $\begin{array}{l}\text { なし。ただし, } \\
\text { その基準は } \\
\text { WTOが利用。 }\end{array}$ & $\begin{array}{l}\text { 検疫及びワクチンを含む } \\
\text { 動物関連措置の国際基準 } \\
\text { を創設。 }\end{array}$ \\
\hline $\begin{array}{l}\text { GATT/ } \\
\text { WTO }\end{array}$ & $\begin{array}{r}1947 / \\
1995\end{array}$ & $\begin{array}{l}\text { ほぼすべての財 } \\
\text { ・サービスの貿 } \\
\text { 易 }\end{array}$ & 149 & $\begin{array}{l}\text { 加盟国を拘 } \\
\text { 束。 }\end{array}$ & $\begin{array}{l}\text { TBT 及びSPS 協定を通じ } \\
\text { た透明性及び紛争解決の } \\
\text { ためのルールを創設 }\end{array}$ \\
\hline $\begin{array}{l}\text { 国際植物 } \\
\text { 防疫条約 } \\
\text { (IPPC) }\end{array}$ & 1952 & $\begin{array}{l}\text { 植物及び植物製 } \\
\text { 品の伝染病及び } \\
\text { 病原体 }\end{array}$ & 157 & $\begin{array}{l}\text { 非拘束。ただ } \\
\text { し,その基準は } \\
\text { WTOが利用。 }\end{array}$ & $\begin{array}{l}\text { 検疫を含む植物関連措置 } \\
\text { の国際基準を創設 }\end{array}$ \\
\hline OECD & 1961 & $\begin{array}{l}\text { 国際的な規制要 } \\
\text { 件，基準及び政 } \\
\text { 策の統一 }\end{array}$ & 30 & なし。 & $\begin{array}{l}\text { 特定品種の遺伝子組成と } \\
\text { 政策展開に関するコンセ } \\
\text { ンサス文書。 }\end{array}$ \\
\hline $\begin{array}{l}\text { コーデック } \\
\text { ス委員会 } \\
(\mathrm{CODEX})\end{array}$ & 1962 & $\begin{array}{l}\text { 食品の組成, 衛 } \\
\text { 生要件及び表示 } \\
\text { の発達 }\end{array}$ & 175 & $\begin{array}{l}\text { なし。ただし, } \\
\text { その基準は } \\
\text { WTOが利用。 }\end{array}$ & $\begin{array}{l}\text { 組成及び表示を含む国際 } \\
\text { 食品基準を創設。 }\end{array}$ \\
\hline $\begin{array}{l}\text { 地域取り } \\
\text { 決め }\end{array}$ & $\begin{array}{l}1990 \\
\text { 年代 }\end{array}$ & $\begin{array}{l}\text { 規制に関する科 } \\
\text { 学の統一 }\end{array}$ & 二国間 & なし。 & $\begin{array}{l}\text { 地域協定, 相互承認合意, } \\
\text { 公式対話及び共同研究。 }\end{array}$ \\
\hline $\begin{array}{l}\text { バイオセ } \\
\text { ーフティ } \\
\text { に関する } \\
\text { カルタへ } \\
\text { ナ議定書 }\end{array}$ & $\begin{array}{r}2003 \\
\text { (発効) }\end{array}$ & $\begin{array}{l}\text { 遺伝子改変生物 } \\
(\mathrm{LMO}) \text { の国境 } \\
\text { 間移動 }\end{array}$ & $\begin{array}{r}\text { 締約 } \\
(135) \\
\text { 署名はよ } \\
\text { り少ない }\end{array}$ & なし。 & $\begin{array}{l}\text { LMO の国境間移動が起 } \\
\text { こる前に輸入国の同意が } \\
\text { 必要 }\end{array}$ \\
\hline
\end{tabular}

(出所) Buckingham and Phillips（2001）, 渡部（2003）を参考に筆者作成

(加盟国数は2006/12月付にアップデートしている)

措置に対する米国・カナダ・アルゼンチンによる訴状を審査した紛争処理パネ ル (以下パネル $)$ の最終報告が出された ${ }^{19)}$ 。今後の展開を考えれば，紛争はま だ完全な決着をみたとはいえないが，ここではひとまずWTOでは何が議論さ れ，何が決定されたのか，そしてその判断の持つ意味はなにか，について述べ る。

紛争の発端となったのは，EUの GM 規制と「事実上のモラトリアム」であ 
る。1999年 6 月にデンマーク，ギリシャ，フランス，イタリア，ルクセンブル クは，欧州委員会に対して GMO 規制の改正（表示規則，トレーサビリティ， 予防原則の制度化）を求め，欧州委員会はその要求を受け，新規の認可に対し て「事実上のモラトリアム」を設けることを宣言した。この「事実上のモラト リアム」に対して，2001年頃からアメリカ・カナダはWTOを通じて圧力をか けていたが，2004年 4 月にアメリカ・カナダが申立書を提出し，同7月パネル が設置されている。そして，2006年 2 月27日に中間報告書，冒頭のように最終 報告書が 9 月29日に出されている。

パネルは，まず，EUの承認手続におけるリスク評価の根拠が SPS 協定に照 らして適切かどうかを問題にした。そこでは，EU立法の下であり得るリスク はSPS協定がカバーするタイプのリスクと結論付けたが，リスクを考慮する EUの権利は問題にされていない。つまり，カルタへナ議定書と同様に，リス ク評価を含めた輸入国サイドの政策主権を確認したといえる。その上でパネル は，モラトリアムの期限である1998年10月から2003年 8 月29日の期間において， 24の製品の承認について完了していない事実に触れ，この点はSPS 協定違反で あるとした（しかし，EUは既にモラトリアムは解除しており，この点は実体 的な意味を持たない)。そして，EUが承認した GM製品の禁止を続ける先の 6 つの $\mathrm{EU}$ 諸国のセーフガード措置についてパネルは，EU委員会のリスク評価 は十分なものであり，各国の措置は根拠にそしく，SPS協定違反であると判断 している。

結論のみいえば，パネルはEUモラトリアムの違法性を確認している。この 「勝訴」の判決に，米国（および産業界）の反応は，GMOの安全性に対して WTOのお墨付きを得たと色めきたつが，それは，WTOの判断を正しく受け止 めているとは，とてもいえないだろう。先に触れたように，パネルはバイオテ クノロジー使用製品の安全性や同種の産品に関する問題, そして, EU法と WTO協定との関係には言及せず，論点をあくまで「手続き」に限定している 点に注意が必要である。つまりWTOは，GMOやバイオテクノロジーに対し 
て具体的・実体的な判断を下していないのだ。北林（2006）は，この判断によ って GMOの物理的・社会的リスクの影響を見極められず，その導入をためら つているアフリカ諸国を始めとする多くの国々の GM作物導入がこの裁定によ り促されたり，強制されたりすることはあり得ないと指摘する。

\section{2. 国際GM規制レジームの今後}

ここでは，今後の GMO貿易と国際 GM 規制レジームについて若干の展望を 記し，本稿のまとめとする。筆者は山川（2007）において，米国産牛肉を事例 として安全性問題と国際貿易およびWTO体制との関係について, 日米BSE交 渉およびEUの成長ホルモン注射牛肉への規制をめぐる紛争事例に検討を加え ている。そこでは，自国産業の利益実現のため「売ること」を目的とした，い わば重商主義的な「自由貿易」の論理に基づくアメリカの農産物・食品貿易戦 略が確認されるとともに，WTO（およびその紛争処理システム）は，単なる 自由貿易推進型の政策判断を行っているのではなく, 各国の政策主権との間で バランスをとっていることを明らかにした。その状況を山川（2007）では， WTOの「摇らぎ」と呼んだ。

成長ホルモンのケースでも, GMOのケースでも, WTOはリスク評価の重要 性を強調している。つまり，WTOは，貿易制限を採用するにあたっては，一 定の手続きを経なければならず，「安全性」や「予防」という主張を繰り返す だけでは，不十分であるとの認識を持っているということである。これは， 「ルールに基づく貿易」と概念規定される現代の国際貿易にあっては，ある程 度納得がいくものである。問題は, その「ルール」がどのように形成されてい くかた。安全性問題に関するWTOのパネルの判断は, リスクガバナンス （GMOの場合，承認制度の決定）は, 各国の主権に基づくという，EUが主張 してきた路線を基本的に受け入れていると思われる ${ }^{20)}$ 。加えてWTOは，「工 ビ・カメパネル」,「アスベストパネル」といった環境・安全性関連の判例にお いても ${ }^{21)}$, 環境・安全性問題に配慮した判断がみられ，一部ではWTOの「グ 
リーン化」といった評価もなされている22)。総合的な評価にはなお時間がかか るが，環境や安全性に関するWTOの意思決定が, 必ずしも貿易自由化一辺倒 ではないという事実には留意しなければならないだろう。

では，国際 GM規制レジームの今後の行方はどうなるのであろうか，若干の 私見を述べたい。EUのリスクガバナンスは, 自由貿易派の諸国への一定の対 抗軸となっていると評価できる(平川, 2003b)。その一方で EUの戦略は, 一 定程度以上の時間を要するWTOの紛争処理システムを用いた「時間稼ぎ」で あるとみることも出来よう。WTO協定の解釈に基づき展開されるパネルの判 断に任せることの大きな問題として, 実体的な判断がいつまでたっても下され ない可能性があるとともに, 紛争にかかる取引費用と貿易制限による経済厚生 の悪化が懸念される。そのような状況のもと, 解決の一つの方向性としては, 現段階で発効しているMEAであるカルタへナ議定書に基づく貿易規制レジー ムの拡張 ·強化が考えられる。しかしカルタヘナ議定書に対しては, 国際協調 を促進するようなメカニズムが備わって抢らず，「保護主義クラブ」を制度的 に担保するものだとする厳しい批判がある（Hobbs, Hobbs and Kerr, 2005）。ア メリカの議定書への不参加問題を含め,「つぎはぎ」の規制枠組みの中でカル タヘナ議定書をどのように改善していくかという点が, 今後議論される必要が あろう。

最後に，「保護」について言及し，稿を終えることとする。Falkner（2004） は, GMO をめぐる紛争は環境 NGO や消費者を巻き込んだ広範な社会運動であ り, 貿易をめぐる伝統的な保護主義や非関税障壁の議論とは異なる性質を有し ていることを強調する ${ }^{23)}$ 。先述したGMOに起因する広範な「リスク」は， GMO 貿易とその規制をめぐる主張が，単なる保護主義では説明しきれないこ とを示唆している。そして, そのリスクに最もさらされているのは, まぎれも なく途上国である。カルタヘナ議定書を中心とした国際規制レジームと自由貿 易レジームとの関係の検討とともに，途上国でのバイオセーフティをいかに担 保し，社会経済的なインパクトを緩和していくかを考えていかねばならないだ 
ろう。UNEPによるカルタヘナ議定書履行・バイオセーフティ確保に向けたキ ヤパシティ・ビルディング政策の検討といつた作業が，その第一歩になるので はないだろうか24)。

Note: 本稿執筆にあたり, 櫻井公人先生 (立教大学) および匿名のレフェリ 一からのコメントが大変有益であった。記して感謝する。もちろん，ありうべ き䛊りは筆者の責任である。

注

1 ）安全性問題とは, 人体への影響を指す「食品安全性」と, 環境・生態系への影響 を意味する「環境安全性」に分類できる。そして, 感染症をはじめとする多くのこれ ら「安全性問題」は,グローバリゼーションの帰結として捉えられると思われる。す なわち, 世界大で生産の効率性が追及され，新たな商品化のプロセスが進展している ことに起因していると考えている。

2 ) 本稿が主として扱うのは国際的局面における安全性問題とその規制だが, 各国 (特に米欧) 間比較の観点もまた重要である。この点については，さしあたり， Ansell and Vogel eds.（2006）を参照されたい。

3 ）いわゆる「貿易と環境」の領域では, 主に環境污染問題と貿易の関係が問われて きたが，現在，不確実性あるいは将来的な影響が危惧される問題（「安全性問題」）が 登場してきている。それらを総称して本稿では, 「貿易と環境・安全性」と呼ぶこと とする。

$4 ）$ 国際レジームについては，クラズナーによる「国際関係のある領域においてアク ター間で共有される暗黙あるいは明示された原理, 規範, ルール, そして意思決定の プロセスのセット」(Krasner, 1983:2) という定義が広く知られている。本稿で「ルー ル」とは, 法律に加え, WTOの判例により積み重ねられ, 具体的に形成された取り 決めを指す。

5 ）現代の国際貿易は様々なルールの制約下で展開されているが, Sampson ed. (2001) ではこのような状況を「ルールに基づく貿易（Rule-Based Trade）」と特徵付けている。 この観点からは, 例えば知的所有権に関する（TRIPS）協定やWTO農業協定などの 
貿易ルールの政治経済学的分析も注目すべき対象であると考えている。

6) GMO貿易とその規制に関する包括的な研究としては立川・藤岡編（2006）。海外で の先行研究は数多いが，主要な論者による論文集，Falkner ed.（2007）は先端の研究 状況の理解に有益である。

7 ）非貿易的関心事項については，小寺編（2002）および Hoekman and Kostecki (2001:ch13) を参照

$8 ） 1970$ 年代から 80 年代以降, 発展途上国の環境污染と貿易の関係が徐々にクローズ アップされてきた。そして, GATT 時代の紛争解決の場で争われた，アメリカがマグ ロを獲る際にイルカを殺してしまう比率の高い国からのマグロ輸入を禁止したケース （アメリカとメキシコの間で争われた「マグロ・イルカ紛争」）以降，「環境と貿易」 という問題領域が一定の市民権を獲得してきたという経緯がある。

9 ）Bhagwati（2004）は伝統的国際貿易論の立場から，食品安全性問題はラベリング政 策で対応せよとの処方箋を示しているが，幾つかの批判すべき点を挙げることができ る。まずラベリング政策の実施には，輸出国のコンプライアンスと外食産業を含めた 全産業的な実施を担保して，情報を確実に消費者へ提供するかが問われるが，その確 保は容易ではないこと。そして，「地理的表示」か「原産地表示」か，内容が警告的 か中立的かにより情報が大きく変化することが挙げられる。米欧の GMO 紛争が示す ように，ラベルそれ自体が貿易紛争の火種なのである（山川, 2007）。

10）WTOにおける国際環境 NGOの動向については, Mason（2005）における第 4 章 (“The World Trade Regime and Environmental Accountability”) に詳しい。

11）それぞれD・リカード型と F・リスト型の貿易政策論として，一般的には対置でき よう。

12）PPMs とは「Processes and Production Methods」の略語である。PPMsの違いが最終 財の性質に影響を及ぼさない（非産品関連PPMs）場合は, PPMsの違いを理由に貿易 制限を行うことは，WTOルール（TBT協定）のもとでは基本的に禁止されている。 いわゆる「同種の産品（like product）」問題である。

13）この点を含め，SPS協定を中心として貿易と食品安全性問題の制度面を検討したも のとして，山川（2005）がある。

14）国際法を履行し，国内法として発効するプロセスを採用している。この点に関す る研究書としては, Bail, Falkner and Marquared eds. (2002) がある。そこでは, 各国 
のカルタヘナ議定書の履行プロセスなどが検討されている。

15）カルタヘナ議定書においては，GMOではなく，LMOが用いられているが，両者は ほほ同義である。

16）(1)の輸出入は, 輸入締約国の基準に従って行われる場合に限りAIAの適用除外と なる。同じく(3)の輸出入もAIA 手続きを必要とせず, (3)の国内利用について最終的 な決定を行った締約国は，バイオセーフティに関する情報交換センター（BCH）を 通じてその決定を他の締約国に通報する。輸入締約国は自国の国内規制に従いコモデ イティの輸入について決定することができる。

17）リオ宣言の第15条である「予防的アプローチ」を受け制度設計された，国際的な GM規制のためのルールとしてのカルタへナ議定書だが, 交渉過程における反対国と の妥協の結果，具体的な規程が途上国の実態を反映できていないという指摘がある (久野, 2002:190-191)。

18）アメリカ未加盟の背景には，先にみたように，世界随一のGMO生産・貿易国とい う事情がある。国内産業への経済的影響を懸念して国際協定への参加を拒否するとい うアメリカの行動は, 環境規制の国内産業への影響を問題視して離脱した京都議定書 をめぐる行動と，よく似た構図で捉えられるように思われる。

19）WTO(2006), Reports out on biotech disputes. この資料は, 次のWTOのHPからダウン ロード可能である。http://www.wto.org/english/news_e/news06_e/291r_e.htm（2007年 5 月13日アクセス）

20）ただ，EU内部にも問題がある。欧州委員会は，単純な GM作物禁止路線ではなく, 慣行, 有機農業との共存路線を採用しており, フランスなどの慎重派とスペインなど の推進派の間の, 域内の利害調整を進めるという課題が残っている。

21）エビを採取する際にカメの混穫を防ぐ対策をとっていない国からのエビ輸入を制 限するアメリカの措置について争われた「エビ・カメパネル」では, 1998年（第一回） と2001年（第二回）に下された二度の上級委員会の決定が下されている。第一回の判 断では, 他国で発生している環境問題を防ぐ措置であっても, GATT20条（一般的例 外）を適用できるとしたが，アメリカがカメの混穫を防ぐ技術移転政策を不十分にし か実施していない点と南アフリカとその他の国を差別的に扱っている点を問題視し, 正当化がなされなかった。その後, アメリカはガイドラインを改訂するなどして対応 し, 貿易制限を続けた。この制限についてマレーシアは提訴し, 審議を経て第二回の 
判断が下された。そこでは, アメリカによるガイドラインの改訂などの結果, 貿易制 限をGATT20条（g）「有限天然資源の保存に関する措置」に基づき正当化できるとの 判断が下されている。この案件のポイントは，WTOは貿易制限の乱発を奨励したの ではなく, 関連する貿易関係国との環境協定妥結に向けた交渉とセットであることを 条件に，貿易制限措置の発動を許可した点にある。また，EUのアスベスト規制によ る貿易制限を不服としたカナダとの間で争われた「アスベストパネル」では，パネル はGATT20条（b）「人，動物又は植物の生命又は健康の保護のために必要な措置」の 適用により，輸入規制を正当化できるとした。また，その後の上級委員会の裁定では， アスベストとその代替物質を同種の産品とはみなさないと判断された。この案件のポ イントは，有害物質とその代替物質を区別して規制を行うことを認めた点にある。な お，これら WTOの判断を踏まえ，環境保全を促進する貿易政策を展望したものとし て，小島（2003）がある。

22）WTO研究者として著名なゲーリー・サンプソンも, 環境・安全性に関するWTO のポジションをこのように確認している。Sampson ed. (2001) を参照。

23）なお，外国に対して規制する一方で，自国では規制しないといういわゆる「ダブ ルスタンダード」を厳しく律していかねば，「保護」を正当化することはできないで あろう。

24）先進国では一般的に，食品の安全性に対する消費者の関心が高い。そのため，途 上国からの貿易財が先進国のSPS 措置の水準に対応できないことが多く，「輸出障壁」 として大きな問題になっている。それゆえ Roberts, Orden and Josling (2004) では, 途上国への資金・技術援助およびキャパシティ・ビルディングの重要性が強調されて いる。UNEPによる開発途上国向けバイオセーフテイ政策については，幾つかの報告 書をUNEPのバイオセーフティプロジェクトHP (http://www.unep.ch/biosafety/) にお いて閲覽できる（2007年 5 月13日アクセス）。

\section{参考文献}

天野明弘（2006）「貿易と環境の国際的統合化を求めて」環境経済・政策学会編『環境 経済・政策研究の動向と展望』東洋経済新報社。

北林寿信（2006）「遺伝子組み換え作物の将来（その 4) 一-WTO 米欧紛争裁定の真実と その影響」『農林経済』(時事通信社), 6 月 12 日。 
小島道一（2003）「環境保全を促進する貿易政策」寺西俊一編（2003）『新しい環境経済 政策一サステイナブル・エコノミーへの道』東洋経済新報社。 小寺彰編（2002）『転換期のWTO一非貿易的関心事項の研究』東洋経済新報社。 立川雅司・藤岡典夫編（2006）『GMO一グローバル化する生産とその規制』農文協。 寺西俊一 (1992)『地球環境問題の政治経済学』東洋経済新報社。 久野秀二（2002）『遺伝子組み換え作物とアグリビジネス一政治経済学アプローチ』日 本経済評論社。

平川秀幸 (2003a)「南北問題からみた遺伝子組み換え作物」調麻佐志・川崎勝 ・平川秀 幸編著『ハイテク社会を生きる』北樹出版。

平川秀幸（2003b）「バイオセイフティと国際関係」日本政治学会報告論文。 藤岡典夫（2006）「遺伝子組み換え体規制をめぐる予防原則とWTOルールの抵触」立 川雅司・藤岡典夫編（2006）『GMO一グローバル化する生産とその規制』農文協。 森田桐郎（1995）「伝統的貿易理論に対する批判的潮流」森田桐郎編著『世界経済論一 《世界システム》アプローチ』ミネルヴァ書房。

山川俊和（2005）「グローバル化する食品安全性問題とWTO体制一問題構造の把握」 『一橋研究』30(1)。

山川俊和（2007）「食品の安全性をめぐる国際交渉と貿易ルールの政治経済学一米国産 牛肉を中心に」『季刊経済理論』34(4)。

渡部靖夫（2003）「遺伝子組み換え作物をめぐる米・EU貿易摩擦について」農林水産政 策研究所 GMO プロジェクト研究資料。

Ansell, C., D. Vogel eds. (2006), What's the Beef?: The Contested Governance of European Food Safety, MIT Press.

Bail, C., R. Falkner and H. Marquard eds. (2002), The Cartagena Protocol on Biosafety: Reconciling Trade in Biotechnology With Environment and Development, The Royal Institute of International Affairs.

Bhagwati, J. (2000), "On Thinking Clearly about the Linkage between Trade and Environment", Environment and Development Economics, 5(4).

Bhagwati, J. (2004), In Defense of Globalization, Oxford University Press.

Buckingham, D., P. Phillips (2001), "Hot Potato, Hot Potato: Regulating Products of Biotechnology by the International Community", Journal of World Trade, 35(1). 
Falkner, R. (2004), "Trading Food: The Politics of Genetically Modified Organisms", in Hocking, B., S. Mcguire (2004), Trade Politics (2nd Edition), Routledge.

Falkner, R. ed. (2007), The International Politics of Genetically Modified Food: Diplomacy, Trade and Law, Palagrave Macmillan.

Hobbs, A., J. Hobbs and W. Kerr (2005), "The Biosafety Protocol: Multilateral Agreement on Protecting the Environment or Protectionist Club?", Journal of World Trade, 39(2).

Hoekman, B., M. Kostecki (2001), The Political Economy of the World Trading System: From GATT to WTO (2nd Edition), Oxford University Press.

Krasner, S. ed. (1983), International Regimes, Cornel University Press.

Martin, C. (2001), “The Relationship Between Trade and Environment Regimes: What Needs to Change?", in Sampson, G. ed. (2001), The Role of the World Trade Organization in Global Governance, United Nations University Press.

Mason, M. (2005), The New Accountability: Environmental Responsibility across Borders, Earthcan.

OECD (1999), Food Safety and Quality: Trade Considerations.

Phillips, P., W. Kerr (2000), "The WTO versus the Biosafety Protocol for Trade in Genetically Modified Organisms", Journal of World Trade, 34(4).

Roberts, D., D. Orden and T. Josling (2004), "Sanitary and Phytosanitary Barriers to Agricultural Trade: Progress, Prospects, and Implications for Developing Countries", in Merlinda, D., A. Winters eds. (2004), Agriculture and the New Trade Agenda Creating a Global Trading Environment for Development, Cambridge University Press.

Sampson, G. ed. (2001), The Role of the World Trade Organization in Global Governance, United Nations University Press. 


\title{
Summary
}

\section{GMO Trade and the International Regulation Structure and Perspective of the International Regulations}

\begin{abstract}
Toshikazu Yamakawa
International dispute concerning the trade and "safety issues" have significant implication. It is how to control the trade goods which have the characteristic caused by the use of the specific chemicals or additives, and biotechnology, especially "Genetically Modified (GM) technology".

In this article, we explore GMO trade and the international regulations. Especially we focus on "The Cartagena Protocol on Biosafety". Aim of this paper is clarifying the structure of international regulation regimes concerning GMO trade and showing the perspective of future GMO regulation.
\end{abstract}

